\title{
HIV Testing: Support for Routine Screening
}

Brett Edwards, BSc Pharm, Stephen Vaughan, MD, DTMH

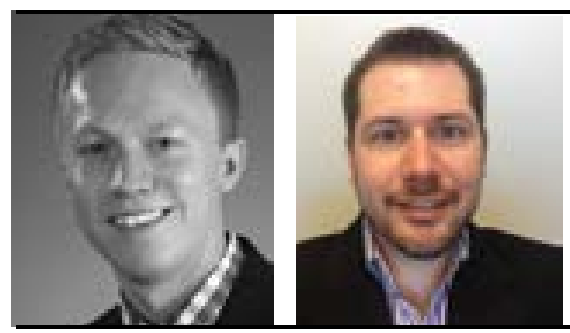

\begin{abstract}
About the Authors
Brett D. Edwards, BSc Pharm is a medical student at Cumming School of Medicine, University of Calgary in Calgary, Alberta. Stephen D. Vaughan, MD, DTMH, is a staff physician, infectious diseases consultant and clinical assistant professor in the Department of Medicine, Division of Infectious Diseases, University of Calgary in Calgary, Alberta.
\end{abstract}

\begin{abstract}
Summary
This article discusses the recent evolution of human immunodeficiency virus (HIV) screening recommendations with significantly expanded role for routine HIV testing. After the Centre for Disease Control (CDC) released recommendations for routine screening in 2006, it was anticipated that the United States Preventive Services Task Force (USPSTF), a national body charged with providing evidence-based recommendations for preventive services, would follow shortly. However, they refrained, citing a lack of evidence at the time to make such a recommendation, and maintained a recommendation for risk-based screening. Following an analysis of recent literature, in 2013 the USPSTF finally made a recommendation for routine HIV screening on the grounds of new evidence. The recommendations are based on the clinical benefit, the failures of risk-based screening, cost-effectiveness data with reduction in HIV related morbidity/mortality, and lower rates of transmission. This article highlights some of the literature that accounted for the change in recommendations and provides a basic review of HIV testing techniques available to the internists and the recommendations for routine screening of patients.
\end{abstract}

\section{Résumé}

L'article examine l'évolution récente des recommandations sur le dépistage de l'infection par le VIH, notamment l'expansion de la détection systématique. À la parution des recommandations sur le dépistage systématique du Centre for Disease Control aux ÉtatsUnis en 2006, l'on s'attendait à ce que le Groupe de travail sur les services de prévention de ce pays, organisme chargé d'offrir des recommandations fondées sur des données probantes à propos des services de prévention, emboîte le pas rapidement. Le Groupe s'est abstenu sur le motif de l'absence de données probantes sur lesquelles fonder une telle recommandation et a maintenu sa recommandation de dépistage en fonction du risque d'exposition au virus. Après une analyse documentaire en 2013, le Groupe de travail a enfin recommandé le dépistage systématique au vu des nouvelles données probantes. Les recommandations se justifient par les avantages cliniques, les échecs du dépistage en fonction du risque, des données cout-efficacité illustrant la diminution de la morbidité et de la mortalité liées à l'infection par le VIH et la baisse des taux de transmission. L'article présente la documentation qui a inspiré ces nouvelles recommandations et passe en revue les techniques de dépistage du VIH à la disposition de l'interniste et les recommandations préconisant le dépistage systématique. 
Recently, the United States Preventive Services Task Force (USPSTF) released a highly anticipated recommendation for routine HIV screening of patients at any interaction with health care, which is quite similar to the recommendation made by the Centre for Disease Control (CDC) in 2006. The USPSTF felt that, until recently, there was insufficient efficacy data to support such a practice. This paper provides a review for internists on the basics of human immunodeficiency virus (HIV) testing and highlights recent changes in evidence that have brought about a recommendation to test nearly all patients.

There are multiple techniques available to test for human immunodeficiency virus. The first-generation HIV test uses an enzyme immunoassay (EIA) to detect host IgG to viral lysate (crude proteins). Most tertiary centres now utilize thirdand fourth-generation kits, which simultaneously detect IgM and IgG antibodies to recombinant protein antigens of HIV 1 and 2, or combined viral p24 antigen/HIV IgM/IgG antibody, respectively. Each method reports sensitivity and specificity $>99 \%$ with diagnostic confirmation using the time-proven Western Blot method. ${ }^{1}$ Rapid detection kits are available, using blood or oral secretions and providing results within 30 minutes (compared to 1-2 days for conventional tests). ${ }^{2}$ These kits deliver quick results in an emergent setting (e.g. index case testing prior to initiating post-exposure prophylaxis) and to reduce loss to follow-up in potentially non-compliant patients. Nucleic acid tests determine the presence of viral genetic material, negating the required presence of host antibodies. The benefit is the ability to detect acute HIV infection in the "window-period" of infection, which is $7-10$ days postexposure and prior to seroconversion.

Time to detection of HIV infection continues to decrease, but physicians must be cognizant of potential false negatives. Thirdand fourth-generation tests have shortened time to positivity from 8 weeks post-exposure required in the first-generation tests to 2-3 weeks. The shorter period in fourth-generation tests is due to detection of viral p24 antigen prior to antibody seroconversion. Following detection, diagnosis requires confirmation with Western Blot or immunofluorescent assay (IFA), which can take an additional 2 days upwards to 3 weeks. Depending on time since the predicted exposure, continued risky behaviour, and the sensitivity of the test kit used, the clinicians must consider the possibility of false negative results. In suspected acute infection with negative initial testing, RNA PCR and serology can be rechecked in 2-4 weeks and 3-6 months, respectively. ${ }^{1,3}$

In 2006, the CDC released recommendations for routine testing of all patients aged 13 to 64 years, regardless of risk factors. ${ }^{4}$ At that point, the USPSTF had refrained from making similar recommendations due to a lack of perceived evidence supporting the strategy in addition to elevated risks of false positives, and rather, maintained a risk-based screening guideline. ${ }^{5}$ In 2013, the USPSTF finally released updated recommendations to: 1) screen all pregnant women for HIV including those who present untested in labour, and 2) screen for HIV, in everyone aged 15 to 65 years, as well as those outside this age range who present at increased risk. ${ }^{2}$ Risk status must be individualized, but increased risk may include: men who have sex with men, active injection drug users, those who have had unprotected vaginal and/or anal intercourse, HIV-infected sexual partners, bisexual individuals, persons exchanging sex for drugs or money, and those seeking testing for sexually transmitted infections. ${ }^{2}$ Universal screening is recommended in any setting where the prevalence of HIVpositive status is $\geq 0.1 \%$. Evidence to guide intervals is lacking, but it has been suggested to screen all patients in the above age-range at least once and those at high risk or in a highprevalence setting $(\geq 1 \%)$ annually. ${ }^{2,4}$

Universal screening is not without potential harm. Early HIV detection leads to earlier initiation of lifelong highly active antiretroviral therapy (HAART) with more opportunity to develop adverse events. HAART has been associated with cardiovascular disease due to metabolic issues linked with the medications, as well as the potential for increased bone, liver, and renal disease. ${ }^{2,5}$ Notably, untreated HIV also risks these comorbidities. Additionally, it leads to earlier exposure to negative psychological effects from having a chronic infection associated with stigmatization. True positive HIV diagnosis has been associated with anxiety and depression. The contribution of false positive results, which are infrequent, to these comorbidities is less well established. One must also factor in the potential burden of universal screening that would be placed particularly on primary care centres. However, the USPSTF recommendations received a "Grade A" recommendation, meaning a "high certainty that the net benefit is substantial." Multiple factors have contributed to this updated routine screening recommendation to substantiate the net benefit, including the high diagnostic accuracy of current HIV tests, cost-benefit analysis, and demonstrated improvement in outcomes. ${ }^{4,6,7}$ Additionally, the update recognizes a changing HIV-positive demographic causing issues with perception of what constitutes high-risk status, as well as the success of other routine HIV screening programs in pregnancy and blood-donation clinics. Routine screening reduces the number of HIV-positive patients missed due to absent risk factor reporting and aims to reduce the stigma associated with risk- 
based screening. Both guidelines now endorse a practice of "opt-out" screening. Specifically, informed consent is required with opportunities for patients to ask questions. Then, as part of their general medical care, patients will receive an HIV screen unless they decline or opt-out. This contrasts with previous recommendations that suggest specialized, written consent must be received from patients choosing to opt-in for testing. Opt-out practices consistently perform more HIV screening tests than those using opt-in principles. ${ }^{4}$ Positive test results should be confidentially communicated to the patient by a health care professional, but remain accessible to others caring for the patient.

Universal testing is a cost-effective strategy, even in settings of low prevalence. ${ }^{4,7}$ Computational models demonstrate that routine screening with one lifetime test in low-risk patients and annual testing in high-risk patients costs $\$ 22,382$ per quality adjusted life years (QALY). ${ }^{7}$ Further gains in QALY were possible if screening was linked with earlier initiation of antiretroviral therapy (ART). This cost-effectiveness of routine screening puts it on par with other currently recommended chronic disease screening programs, such as hypertension and breast cancer. ${ }^{4} \mathrm{~A}$ reduction in risky behaviour is argued to be imperative to end an epidemic in the $\mathrm{US}^{7}$ and is a benefit, as demonstrated with routine testing. ${ }^{4}$ However, HIV screening meets an acceptable threshold of cost-effectiveness even before factoring in a reduction in sexual transmission. ${ }^{8}$

Early detection makes a difference on HIV outcomes, yet it has been estimated that about one-third of patients receive a late diagnosis. ${ }^{9}$ Previously, the USPSTF failed to find evidence of clinical benefit with initiating earlier antiretroviral therapy ART $\left(\mathrm{CD} 4 \geq 200 \times 10^{6}\right.$ cells/L). Multiple studies now exist noting morbidity and mortality benefit with early ART, often in the asymptomatic patient. ${ }^{2,6,10}$ In particular, a high-quality randomized trial showed a reduction in serious AIDS-related events, including death, with early treatment (CD4 350-550 $\mathrm{x} 10^{6}$ cells/L). This same study found that in couples with discordant HIV status, those who received earlier treatment had lower rates of transmission than those who initiated ART at $\mathrm{CD} 4 \leq 200 \times 10^{6}$ cells/L. ${ }^{6}$

As mentioned, further benefit to early detection of infection stems from the conclusion that individuals aware of their HIV-positive status reduce high-risk behaviours. These include unprotected intercourse, injection drug use, and sex in exchange for drugs or money. ${ }^{4}$ Some question whether universal screening must be linked to counselling to reap these benefits. The CDC argues that directing people diagnosed with HIV to prevention and care services is essential. Conversely, the benefit of tying counselling to screening is less clear because it may limit the effectiveness and compliance in HIV-negative patients, thus reducing testing numbers. Subsequently, it is not recommended. Rather, counselling is strongly recommended when screening high-risk individuals and in sexually transmitted infection (STI) clinics where risky behaviours are assessed routinely, as a counselling and prevention strategy for all sexually transmitted infection clinics is a beneficial practice. ${ }^{4}$ Combining reduction in high-risk behaviour to curb viral spread with noted morbidity/mortality benefit simply by earlier detection makes routine screening for HIV a necessary inclusion into practice.

Routine HIV screening is not a practice of "testing because we can," but rather a practice with clear clinical and cost benefit. Recent references have supported this practice and enabled the USPSTF to recommend routine screening, which includes screening all patients aged 15 to 65 years upon contact with the health care system and annually in those at increased risk. This is similar to recommendations outlined by the CDC in 2006. There are a variety of testing methods available to screen for HIV. Nucleic acid tests offer the earliest detection at 7-10 days but are costly. Most tertiary centres use third or fourth generation screens, which can detect the virus $2-3$ weeks postinfection and are available in conventional and rapid test kits. Following diagnostic confirmation with Western Blot or IFA, most tests are $>99 \%$ sensitive and specific for HIV, making them a reliable screening protocol that is equivalent to other chronic disease screening programs. The benefits of early treatment outweigh any negative consequences; therefore, routine testing is justified in nearly all patients.

Helpful resource for clinicians interested in further information:

HIV InSite Knowledge Base:

http://hivinsite.ucsf.edu/ - click on 'Knowledge Base' 


\begin{tabular}{|c|c|c|c|c|}
\hline Test & Mechanism of detection & $\begin{array}{l}\text { Post-infection } \\
\text { time to positivity }\end{array}$ & Strengths & Limitations \\
\hline 1st Gen & EIA detecting IgG to viral lysate & 6-8 weeks & Time proven & $\begin{array}{l}\text { Cannot detect viral antigen; } \\
\text { Relatively poor sensitivity and } \\
\text { specificity; Time to positivity }\end{array}$ \\
\hline 2nd Gen & $\begin{array}{l}\text { EIA detecting } \lg \mathrm{G} \text { to recombinant } \\
\text { viral antigen }\end{array}$ & 5 weeks & Time proven; improved specificity & $\begin{array}{l}\text { Cannot detect viral antigen; } \\
\text { Time to positivity }\end{array}$ \\
\hline 2nd Gen & Sandwich EIA to detect $\lg M$ and $\lg G$ & 3 weeks & $\begin{array}{l}\text { Earlier detection of antibodies (IgM) } \\
\text { to both HIV } 1 \text { and } 2\end{array}$ & Cannot detect viral antigen \\
\hline 4th Gen & $\begin{array}{l}\text { Detect IgM/lgG and/or viral p24 } \\
\text { antigen }\end{array}$ & 2 weeks & $\begin{array}{l}\text { Can detect prior to seroconversion; } \\
\text { more timely }\end{array}$ & May miss acute infection \\
\hline WB & Detecting IgG to HIV lysate & 5 weeks & $\begin{array}{l}\text { Reliable; Time-proven; Specificity; } \\
\text { Confirmatory test }\end{array}$ & $\begin{array}{l}\text { Cost; Time; Time to positivity; } \\
\text { False (-) }\end{array}$ \\
\hline IFA & $\begin{array}{l}\text { Fluorescent-tagged antihuman } \\
\text { antibodies detect HIV antibody }\end{array}$ & Days & $\begin{array}{l}\text { Specificity; May clarify indeterminate } \\
\text { WB results }\end{array}$ & User dependent; Time; Cost \\
\hline NAAT & Amplify HIV DNA or RNA & $7-10$ days & $\begin{array}{l}\text { Earliest detection; Can detect acute } \\
\text { infection }\end{array}$ & $\begin{array}{l}\text { Cost, time, skill, 3-5\% false (-) } \\
\text { in established infection }\end{array}$ \\
\hline $\begin{array}{l}\text { Rapid } \\
\text { Tests }\end{array}$ & $\begin{array}{l}\text { Use saliva, blood, or serum to } \\
\text { detect lgM/lgG to HIV }\end{array}$ & $\sim 3$ weeks & $\begin{array}{l}\text { Reduced loss to follow-up; } \\
\text { Possible home use }\end{array}$ & Possible home use; false (-) \\
\hline
\end{tabular}

Table 1. Common Tests Used for HIV Detection: EIA - Enzyme Immunoassay; WB - Western Blot; IFA - Immunofluorescence Assay; NAAT - Nucleic Acid Amplification Test. Reproduced with permission from Kang Cornett and Kirn, Oxford University Press. ${ }^{1}$

\section{References}

1. Kang Cornett J, Kirn TJ. Laboratory diagnosis of HIV in adults: a review of current methods. Clin Infect Dis 2013;57:712-8.

2. Moyer VA, U.S. Preventive Services Task Force. Screening for HIV: U.S. preventive services task force recommendation statement. Ann Intern Med 2013;159:51-60.

3. Niel Constantine. HIV InSite Knowledge Base: HIV Antibody Assays. Available from: http://hivinsite.ucsf.edu/InSite?page=KB. Accessed Jan 25, 2014.

4. Branson BM, Handsfield HH, Lampe MA, et al. Revised recommendations for HIV testing of adults, adolescents, and pregnant women in health-care settings. MMWR: Recommendations and Reports 2006;55(RR-14):1-17.

5. United States Preventive Services Task Force. Screening for HIV: Recommendation Statement [internet]. 2005 [updated 2007 April 2]. Available from: http://www.uspreventiveservicestaskforce.org/uspstf05/hiv/ hivrs.htm. Accessed Jan 21, 2014.
6. Cohen MS, Chen YQ, McCauley M, et al. Prevention of HIV-1 infection with early antiviral therapy. N Engl J Med 2011;365:493-505.

7. Long EF, Brandeau ML, Owens DK. The cost-effectiveness and population outcomes of expanded HIV screening and antiretroviral treatment in the United States. Ann Intern Med 2010;153:778-89.

8. Sanders GD, Bayoumi AM, Sundaram V, et al. Cost-effectiveness of screening for HIV in the era of highly active antiretroviral therapy. N Engl J Med 2005;352:570-85.

9. Centre for Disease Control. Vital signs: HIV testing and diagnosis among adults - United States, 2001-2009. MMWR 1010;59:1550-5.

10. Emery S, Neuhaus JA, Phillips AN, et al. Major clinical outctherapy (ART)naïve participants and in those not receiving ART at baseline in the SMART study. J Infect Dis 2008;197:1133-44. 